\title{
Materials for use in calcium looping technology for CCS - corrosion processes in high-temperature $\mathrm{CO}_{2}$
}

\section{Materiály pro použití v technologii karbonátové smyčky pro CCS - korozní procesy ve vysokoteplotním $\mathrm{CO}_{2}$}

\author{
Poláčková J. ${ }^{1}$, Petrů J. ${ }^{1}$, Janák M. ${ }^{2}$, Berka J. ${ }^{2,3}$, Krausová A. ${ }^{1}$ \\ ${ }^{1}$ Department of Power Engineering, UCT Prague \\ ${ }^{2}$ Department of Gas, Coke and Air Protection, UCT Prague \\ ${ }^{3}$ Research Centre Řež \\ E-mail: Jana.Polackova@vscht.cz
}

Carbon Capture and Storage (CCS) technologies are a perspective solution to reduce the amount of $\mathrm{CO}_{2}$ emissions. One of promising methods is Ca-looping, which is based on carbonation and calcination reactions. During both of these processes, especially calcination, high temperatures $\left(650-950^{\circ} \mathrm{C}\right)$ are required. This means high demands on the corrosion resistance of equipment materials. Therefore, we carried out a stu$d y$ to suggest materials with suitable properties for calciner construction, which have to be particularly heat resistant: stainless steels (AISI 304, AISI 316L and AISI 316Ti) and nickel alloys (Inconel 713, Inconel 738, Incoloy 800H). A special device simulating calciner environment was built for this purpose. Chosen materials were tested in temperature $900^{\circ} \mathrm{C}$, atmospheric pressure and gaseous environment with composition that can be possible in a calciner. The surfaces of materials were evaluated to determine composition and properties of formed oxide layers. High temperature oxidation was observed on all tested materials and oxide exfoliation occurred on some of tested materials $(304,316 \mathrm{~L})$.

\section{INTRODUCTION}

Post-combustion calcium looping enables to capture $\mathrm{CO}_{2}$ from flue gases using the principle of $\mathrm{CaO}$ carbonation. The product of carbonation $-\mathrm{CaCO}_{3}$ is moved to another vessel, where calcination takes place. During the calcination pure $\mathrm{CO}_{2}$ is captured and $\mathrm{CaO}$ regenerated, suitable for another cycle of carbonation. Basic equipment for the calcium looping process consists of two vessels. The first one is carbonator, where $\mathrm{CO}_{2}$ is captured from flue gas in temperature range $450-750^{\circ} \mathrm{C}$. In the second vessel, calciner, temperature above $850^{\circ} \mathrm{C}$ is required $[1,2]$.

High temperatures together with the environment cause higher demands on the corrosion resistance of equipment materials. Although corrosion in pure $\mathrm{CO}_{2}$ is
Technologie záchytu a ukládání uhliku (CCS) jsou perspektivním řešením ke sniženi množství emisi $\mathrm{CO}_{2}$. Jednou ze slibných metod je karbonátová smyčka, která je založena na karbonatačnich a kalcinačnich reakcich. Oba tyto procesy, zvláště kalcinace, vyžadují vysoké teploty $\left(650-950^{\circ} \mathrm{C}\right)$. To znamená vysoké nároky na korozni odolnost materiálu zařizení. Proto jsme provedli studii $k$ navrženi materiálu s vhodnými vlastnostmi pro konstrukci kalcinátoru, které musí být predevšim odolné vůči vysokým teplotám: korozivzdorné oceli (AISI 304, AISI 316L and AISI 316Ti) a slitiny niklu (Inconel 713, Inconel 738, Incoloy 800H). Pro tyto účely bylo postaveno speciální zařizeni simulujici prostředi kalcinátoru. Vybrané materiály byly testovány za teploty $900^{\circ} \mathrm{C}$, atmosférického tlaku a v plynném prostredi se složením, kterého může být dosaženo $v$ kalcinátoru. Povrchy materiálů byly vyhodnoceny z hlediska složení a vlastnosti vzniklých oxidických vrstev. Byla pozorována vysokoteplotni oxidace a na některých z testovaných materiálů $(304,316 L)$ se objevila exfoliace.

almost insignificant, just a slight amount of water can initiate it [3-5]. Flue gas contains also a wide range of other substances, particularly sulphur and nitrogen oxides and $\mathrm{Cl}$ compounds, all of which are soluble in water. In the case of water condensation (e.g. shutdown), they can form strong mineral acids. Also $\mathrm{CO}_{2}$ is soluble in liquid water where it forms $\mathrm{H}_{2} \mathrm{CO}_{3}$ to cause acidification as well. The condensate can reach pH 3 and even lower. The corrosion rate in $\mathrm{CO}_{2}$ containing low concentration of water can reach up to $20 \mathrm{~mm} / \mathrm{y}$ [3]. During $\mathrm{CO}_{2}$ capture, some part of the aforementioned substances pass also into the outlet gas as impurities, especially humidity, inert gases $\left(\mathrm{N}_{2}, \mathrm{Ar}\right)$, oxygen and $\mathrm{SO}_{2}$. In the case of a carbonate loop, they account for approximately $5 \mathrm{~mol} \%$ of the outlet gas [6]. Thus, the metal surfaces of the equipment used in CCS technologies can be strongly attacked by corrosion during any technical breaks that 
require cooling down of equipment. Therefore, materials with good heat and corrosion resistance, such as stainless steels and nickel superalloys, should be used for the equipment construction. These materials have to be tested to prove their resistance and to suggest the most suitable alloy for CCS equipment construction.

A method for reducing corrosion involves the formation of a protective oxide layer. These layers work as a barrier between material surface and environment. Their properties are dependent on many factors, which are generally defined by the interaction of a metal and a certain environment. A good protective layer has to be enough compact, excessive thick layers are problematic, because exfoliation can appear. F. Rouillard and T. Furukawa show in [7] that steels with 9-12\% Cr oxidize and carburize in $\mathrm{CO}_{2}$ environment within temperatures above $500^{\circ} \mathrm{C}$. Thick duplex oxide layers were formed in $500-600^{\circ} \mathrm{C} \mathrm{CO}_{2}$. The outer layer is composed of $\mathrm{Fe}_{2} \mathrm{O}_{3}$ and $\mathrm{Fe}_{3} \mathrm{O}_{4}$, the inner part of layer contains mixed $\mathrm{Fe}-\mathrm{Cr}$ spinel oxide. Grains of the outer oxide layers are considerable bigger. For efficient corrosion protection is important especially small-grained spinel oxide layer.

In the $\mathrm{Ca}$ looping environment $\mathrm{Cr}$ rich carbides can be formed below the oxide layer (Figure 1), while carburization depth grows with time according to a parabolic law [7-9]. The mechanism of carburization in

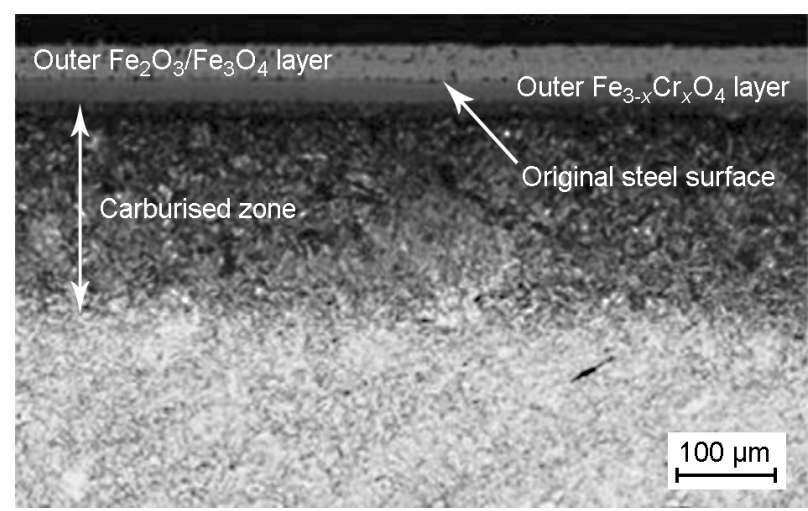

Fig. 1. $12 \mathrm{Cr}$ steel cross section after $5000 \mathrm{~h}$ exposure in $\mathrm{CO}_{2}$ at $550^{\circ} \mathrm{C}$ and 200 bar [7]

Obr. 1. Metalografický výbrus $12 \mathrm{Cr}$ oceli po $5000 \mathrm{~h}$ expozici $\checkmark \mathrm{CO}_{2}$ za $550^{\circ} \mathrm{C}$ a 200 bar [7]
$\mathrm{CO}_{2}$ environment is explained in [8] by diffusion of $\mathrm{CO}_{2}$ species through pores in an oxide layer while reactions (1) and (2) are in local equilibrium.

$$
\begin{gathered}
\mathrm{CO}_{2}=\mathrm{CO}+1 / 2 \mathrm{O}_{2} \\
2 \mathrm{CO}=\mathrm{CO}_{2}+\mathrm{C}
\end{gathered}
$$

Because of oxide forming reactions the oxygen potential tends to a low value on the metal/oxide interface. Therefore, carburisation can occur. These microstructural changes have significant influence on the equipment lifetime, because mechanical properties of material are be changed.

In this study we carried out the first exposure of four stainless steels and three nickel alloys (Table 1) to compare their behaviour in $900^{\circ} \mathrm{C} \mathrm{CO}_{2}$. This experiment gives information about possible behaviour of materials in calciner environment.

\section{EXPERIMENT}

\section{Materials}

Stainless steels and nickel alloys were selected for the exposure because of their heat and corrosion resistivity and availability.

The content of alloying metals is summarized in Table 1. AISI 304, AISI 316L and 316Ti are heat resistant stainless steels with good corrosion properties. The nickel alloys are Inconel 713, Inconel 738. Incoloy $800 \mathrm{H}$ is an alloy of iron and nickel used in chemical and power industry for high temperature applications.

The material is assigned simply as a nickel alloy in this paper for briefness. Inconel and Incoloy materials are declared to be very stable at high temperatures and they should resist to carburization. Compare to stainless steels their heat resistance is higher [11]. However, stainless steels are machinable more easily and significantly better affordable.

All the samples were polished to 4000 grit surface finish and degreased ultrasonically and by rinsing with ethanol/acetone. For the exposure they were placed into special ceramic holders.

Tab. 1. Chemical composition of tested materials (wt.\%) [10] / Chemické složení testovaných materiáli̊ (hm.\%) [10]

\begin{tabular}{|l|c|c|c|c|c|c|c|c|c|c|c|c|c|c|}
\hline Material & Fe & $\mathbf{C r}$ & $\mathbf{N i}$ & $\mathbf{C}$ & $\mathbf{M o}$ & $\mathbf{T i}$ & $\mathbf{A l}$ & $\mathbf{M n}$ & $\mathbf{S i}$ & $\mathbf{C o}$ & $\mathbf{W}$ & Ta & S & P \\
\hline AISI 304 & Base & $17-19.5$ & $8-10.5$ & $<0,07$ & & & & & & & & & & \\
\hline AISI 316Ti & Base & $16.5-18.5$ & $10.5-13.5$ & $<0.08$ & $2-2.5$ & $0.4-0.7$ & & & & & & & & \\
\hline AISI 316L & Base & $16.5-18.5$ & $10-12$ & $<0.03$ & $2-2.5$ & & & $<2$ & $<1$ & & & & $<0.015$ & $<0.045$ \\
\hline Inconel 738 & $<0.35$ & $15.7-16.3$ & Base & $0.15-0.2$ & $1.5-2$ & $3.2-3.7$ & $3.2-3.7$ & & & $8-9$ & $2.4-2.8$ & $1.5-2$ & & \\
\hline Inconel 713 & $<5$ & $11-14$ & Base & 0.02 & $3.5-5.5$ & 1 & $5.5-6.5$ & $<1$ & & & & & & \\
\hline Incoloy 800H & $>39.5$ & $19-23$ & $30-35$ & $0.05-0.1$ & & $0.15-0.6$ & $0.15-0.6$ & & & & & & & \\
\hline
\end{tabular}




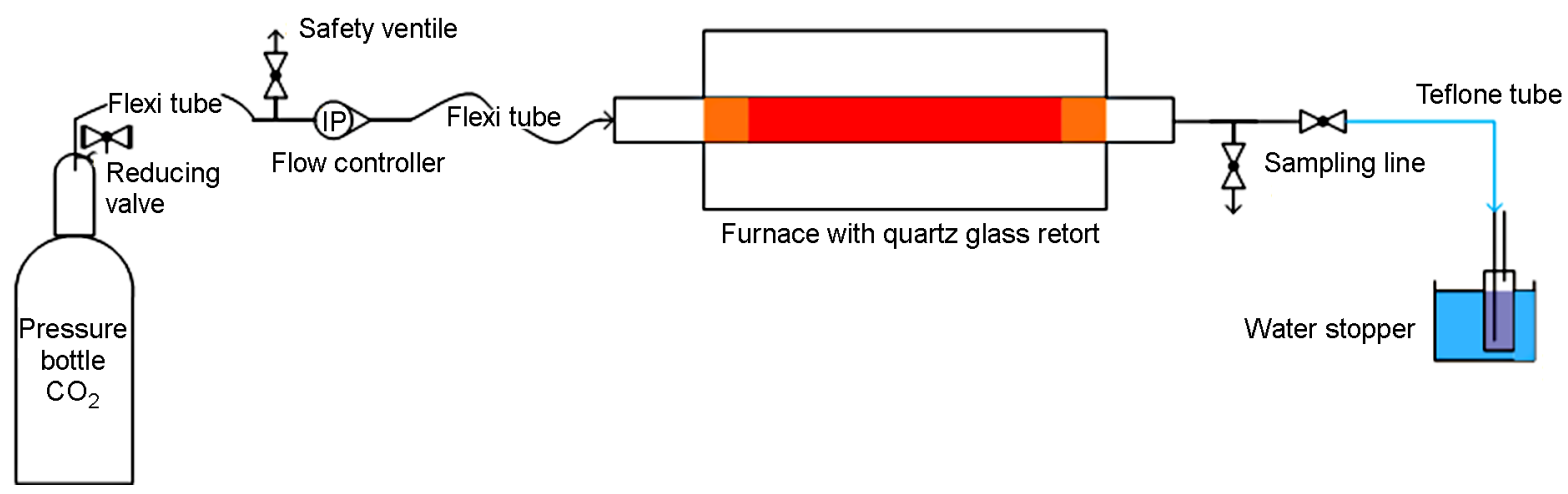

Fig. 2. Experimental device schema

Obr. 2. Schéma experimentálního zařízení

\section{Experimental device}

A high-temperature device for corrosion tests was designed and constructed for the Ca looping materials tests (Figure 2). Samples are placed into a tube furnace with retort made of quartz glass, which is fed with $\mathrm{CO}_{2}$ from a pressure bottle. This type of device is suitable for experiments at high temperatures up to $1000^{\circ} \mathrm{C}$ and tests in gaseous environment.

Technical carbon dioxide in pressure bottle (purity 99.5 vol.\%) was used as working gas. To eliminate adverse effect of ambient air in the system, the quartz glass retort and all tubes were evacuated after placing samples into the furnace and afterwards the system was filled with working gas. Further the system was evacuated and filled with working gas again. The flow of working gas was set by a ball valve and regulated by a small ball valve on a rotameter. The flow of working gas was continuously measured during the experiment by a flow meter.

All the tubes contained in the device are made of stainless steel and flexi tubes are Teflon in core, behind the quartz glass retort was a Teflon tube ended to a water stopper to prevent leaking ambient air to system. The experimental setup was following: the flow of working gas was set to $30 \mathrm{~cm}^{3} \mathrm{~min}^{-1}$ directly after settings before experiment. The pressure in the system was reduced to atmospheric pressure by a reducing valve on the bottle with working gas. Warming-up started at $20^{\circ} \mathrm{C}$ with temperature ramp $5^{\circ} \mathrm{C}$ per minute to temperature $900^{\circ} \mathrm{C}$ that was kept for 200 hours. After the experiment was finished, the samples were cooled down within temperature ramp $-1^{\circ} \mathrm{C}$ per minute to final temperature $30^{\circ} \mathrm{C}$.

\section{Analyses}

The gravimetric data of all samples were evaluated to determine the weight changes of the materials. Further surface analyse was made with scanning electron microscopy (SEM). Microstructures and layers composition were studied using a scanning electron microscope with electron source tungsten filament (cathode) and energy range $30 \mathrm{kV}$. The elemental microanalysis was made by the method of Energy-dispersive $\mathrm{X}$-ray spectroscopy (EDS).

The top layer of corrosion products created on tested materials was identified by XPS method. Samples were be analysed by the XPS with the ESCA Probe P apparatus equipped with $\mathrm{Al} \mathrm{K \alpha}(1486.6 \mathrm{eV}) \mathrm{X}$-ray source with monochromator and a hemispherical analyser. The size of the analysed area is approximately $1 \mathrm{~mm}^{2}$. Ar ions of $5 \mathrm{keV}$ energy are used for ion sputtering.

\section{DISCUSSION AND RESULT ANALYSIS}

\section{Gravimetry}

The gravimetric results (Figure 3) show that all the samples gained a small amount of mass. The most significant mass gain had stainless steels $304\left(0.65 \mathrm{~g} / \mathrm{m}^{2} \mathrm{~h}\right)$. This material had excessive thick oxide layer with considerable exfoliation (Figure 4a). Materials 316L, $316 \mathrm{Ti}$ and $800 \mathrm{H}$ showed exfoliation as well, especially on sides of the samples (Figure $4 \mathrm{~b}$ ). Stainless steel $316 \mathrm{Ti}$ has the lowest weight gain $\left(0.09 \mathrm{~g} / \mathrm{m}^{2} \mathrm{~h}\right)$. Both Inconels 738 and 713 had compact oxide layers (Figu-

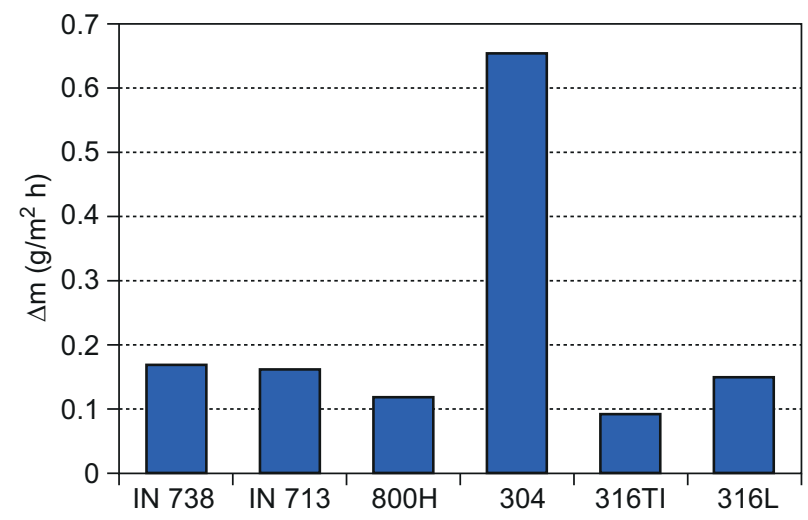

Fig. 3. Gravimetric results Obr. 3. Výsledky gravimetrie 


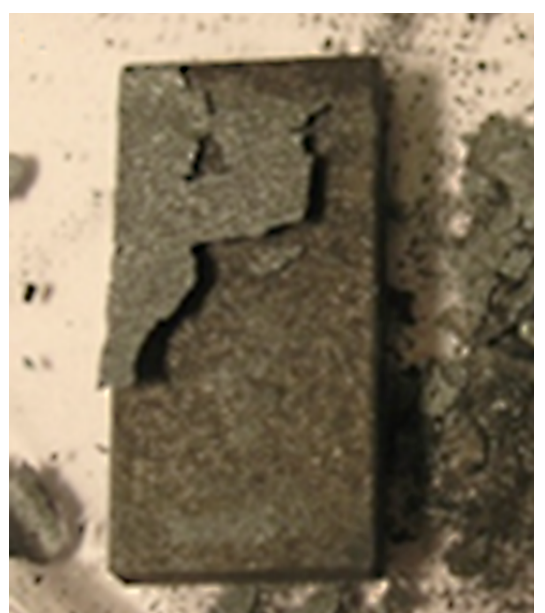

a) steel 304

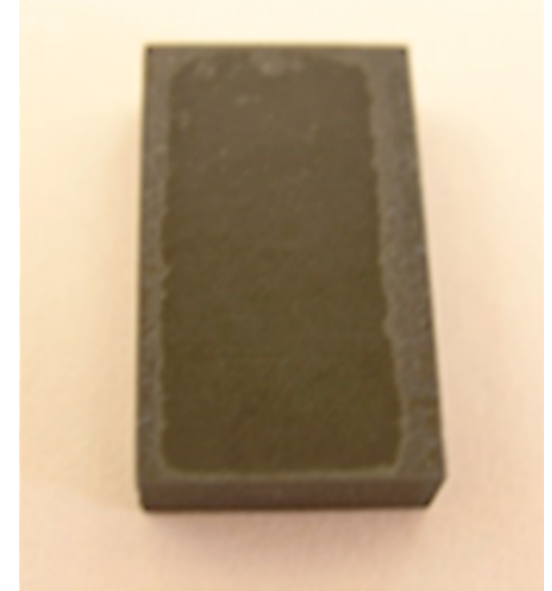

b) Incoloy $800 \mathrm{H}$

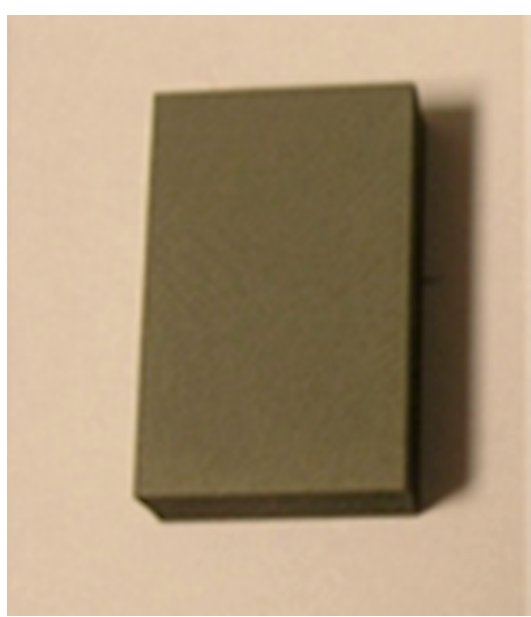

c) Inconel 738

Fig. 4. Materials after $200 \mathrm{~h}$ in $900^{\circ} \mathrm{C} \mathrm{CO}_{2}$ exposure: a) steel 304 ; b) Incoloy $800 \mathrm{H}$, c) Inconel 738 Obr. 4. Materiály po expozici $200 \mathrm{~h} \mathrm{v} 900^{\circ} \mathrm{C} \mathrm{CO}$ : a) ocel 304; b) Incoloy $800 \mathrm{H}$, c) Inconel 738

re 4c). According to these results, we can assume that no corrosion damage of the samples occurred. However, excessive high temperature oxidation was observed certainly on stainless steel 304 and on $316 \mathrm{~L}$ in lower grade.

\section{SEM-EDS surface analysis}

Figures 5-7 show the microstructure of the oxide layers formed on the materials during the exposure in $900^{\circ} \mathrm{C} \mathrm{CO}_{2}$ for 200 hours. On the layer of stainless steel 304 is significant exfoliation, the layer is very thick and contains rough grains. EDS analysis showed that the exfoliated parts of layer contained almost only iron oxides, while in the inner layer, which was left on the sample surface, was higher content of $\mathrm{Cr}, \mathrm{Ni}$ and $\mathrm{Mn}$.

The layers formed on the stainless steels $316 \mathrm{~L}$ and 316Ti were similar. They both are composed from finegrained oxide layer on the metal surface and on top of this layer are significant bigger grains of oxides, which are localized regularly. The difference is in the shape of these bigger grains: on $316 \mathrm{Ti}$ is the shape cubic, but on the $316 \mathrm{~L}$ are needle crystals of smaller size. These materials are of very similar composition (Table 1), 316L has slightly lower $\mathrm{Ni}$ and $\mathrm{C}$ content, but can contain small concentrations of S, P, Mn and Si. Furthermore, several cracks were observed on the oxide layer of $316 \mathrm{~L}$. The oxide layer of this material was evaluated as possibly prone to cracking also in [12]. The stainless steel 316 Ti is alloyed with $0,4-0,7 \% \mathrm{Ti}$. The oxide layers of both 316 steels contain $\mathrm{Fe}, \mathrm{Cr}$, Mn and $\mathrm{Ni}$ oxides. In the grains of bigger size were found higher contents of $\mathrm{Ni}$.

All of nickel superalloys formed very fine-grained layers. To see their structures, magnification 1000 times and bigger was used. The most interesting was the layer of Incoloy $800 \mathrm{H}$ that was covered with a net-structure of even finer grains (Figure 6b). This layer contained mainly
$\mathrm{Cr}, \mathrm{Mn}$ and $\mathrm{Ti}$ with small amount of $\mathrm{Fe}$, which are usual oxide elements in $\mathrm{Ni}-\mathrm{Fe}$ alloys [5, 13-15]. Oxide layers of both inconels were formed mainly of $\mathrm{Ti}$ and $\mathrm{Cr}$ oxides with low amount of $\mathrm{Ni}$. The structures of these layers are even and formed from fine globular oxide particles, that is especially significant on Inconel 713. Particularly the fine-grained structure of the oxides ensures good adhesion of the layer and lower predisposition to cracks of exfoliation appearance.

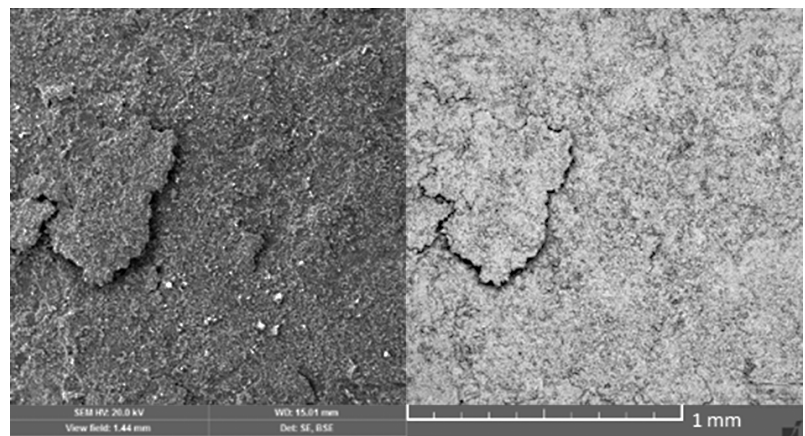

a) AISI 304

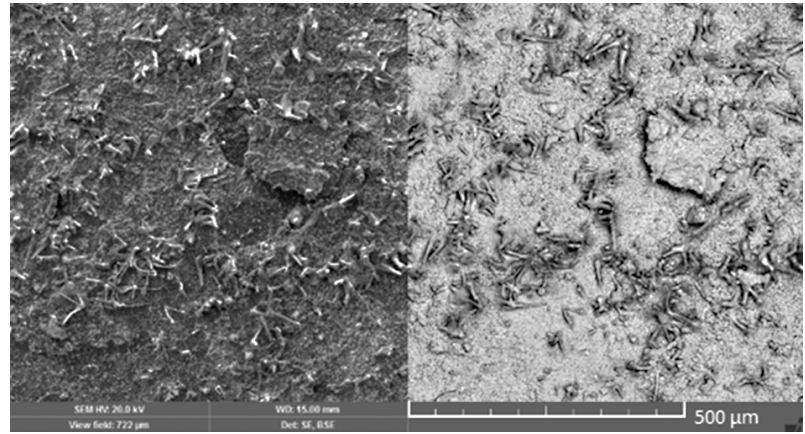

b) AISI 316L

Fig. 5. Microstructures of oxide layers: a) AISI 304, b) AISI $316 \mathrm{~L}$

Obr. 5. Mikrostruktury oxidických vrstev 


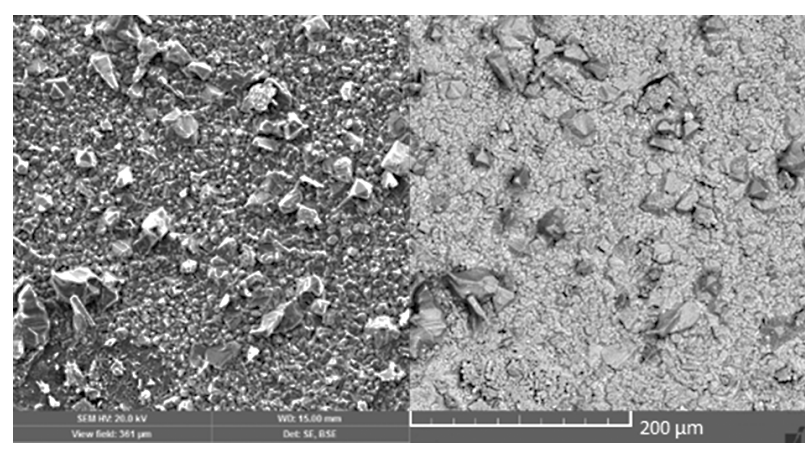

a) AISI 316Ti

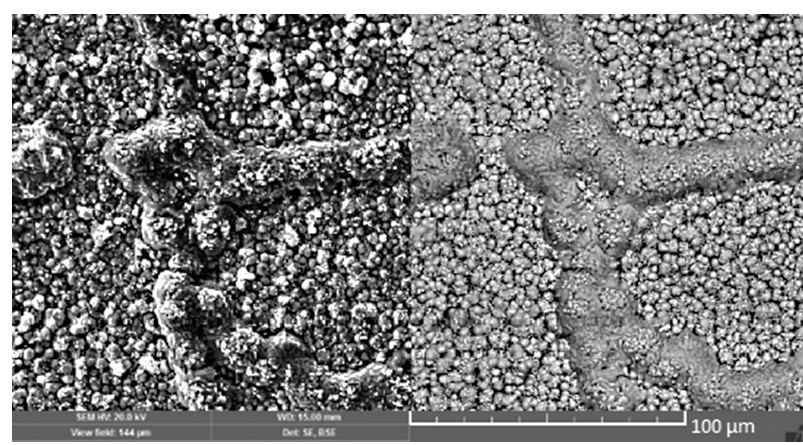

b) Incoloy $800 \mathrm{H}$

Fig. 6. Microstructures of oxide layers: a) AISI 316Ti, b) Incoloy $800 \mathrm{H}$

Obr. 6. Mikrostruktury oxidických vrstev

\section{XPS analysis}

On the surface of all samples is present atmospheric contamination $\mathrm{C}$, which can be partially reduced by surface sputtering. Sputtering rate depends on time and on surface structure - sputtering time 10-12 min was chosen for the samples analysed in this study. The basic states of material surface compositions were measured with the

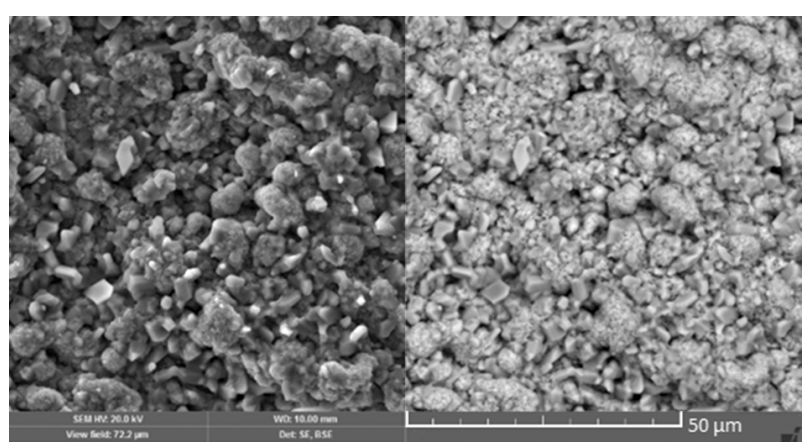

a) Inconel 783

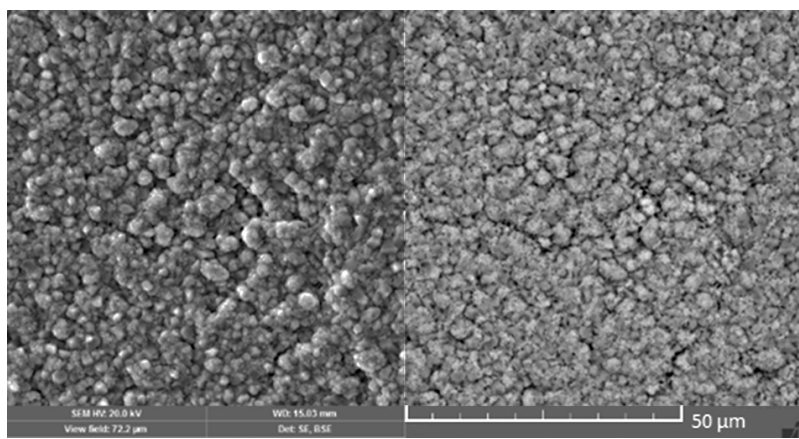

b) Inconel 713

Fig. 7. Microstructures of oxide layers: a) Inconel 783, b) Inconel 713

Obr. 7. Mikrostruktury oxidických vrstev

same Ar sputtering time to decrease the influence of the atmospheric $\mathrm{C}$ on the content of the other elements. The results are shown in Table 2 .

It can be summarized that surface oxidation occurred at all materials in high rate with the obvious migration of following metals: $\mathrm{Ti}, \mathrm{Cr}, \mathrm{Mn}$, but also Fe. These metals move through material to the surface, where they mostly create oxide layers. Other metals, manly $\mathrm{Ni}$ and Mo are

Tab. 2. Comparison of materials' surface composition before (BS - basic state) and after exposure (exp.) in at.\% / Porovnání povrchových složení materiálů před (BS-základní stav) a po expozici (exp.) i at.\%

\begin{tabular}{|c|c|c|c|c|c|c|c|c|c|c|c|}
\hline & & $\mathrm{C}$ & O & $\mathrm{Ni}$ & $\mathrm{Cr}$ & Mo & Co & $\mathbf{T i}$ & $\mathrm{Nb}$ & $\mathrm{Fe}$ & Mn \\
\hline \multirow{2}{*}{ IN1(738) } & BS & 33.0 & 7.3 & 38.7 & 10.3 & 1.8 & 6.9 & 2.0 & - & & \\
\hline & exp. & 11.0 & 59.1 & - & 2.4 & - & - & 27.4 & - & - & - \\
\hline \multirow{2}{*}{ IN2(713) } & BS & 24.7 & 6.2 & 55.4 & 7.2 & 4.0 & - & - & 2.5 & & \\
\hline & exp. & 7.8 & 58.8 & - & 18.4 & - & - & 15.1 & - & - & - \\
\hline \multirow{2}{*}{304} & BS & 41.1 & 2.4 & 4.6 & 9.8 & - & - & - & - & 42.0 & - \\
\hline & exp. & 22.2 & 44.6 & 4.5 & 15.9 & - & - & - & - & 12.4 & - \\
\hline \multirow{2}{*}{$800 \mathrm{H}$} & BS & 29.3 & 3.1 & 22.4 & 12.3 & - & - & - & - & 33.1 & - \\
\hline & exp. & 7.6 & 50.2 & 2.9 & 12.4 & - & - & 3.3 & - & 4.8 & 18.8 \\
\hline \multirow{2}{*}{$316 \mathrm{Ti}$} & BS & 30.0 & 2.0 & 5.5 & 12.4 & 2.6 & - & - & - & 47.6 & - \\
\hline & exp. & 6.4 & 49.3 & 2.2 & - & - & - & - & - & 40.3 & 1.8 \\
\hline \multirow{2}{*}{$316 \mathrm{~L}$} & BS & 18.4 & 3.3 & 7.1 & 12.1 & 1.6 & - & - & - & 57.5 & - \\
\hline & exp. & 13.4 & 59.8 & 3.6 & 6.1 & 0.4 & - & - & - & 13.8 & 2.86 \\
\hline
\end{tabular}


in oxide layers present in significantly lower amount compare to the basic metal composition. $\mathrm{Ni}$ is less prone to oxidation reactions compared to iron. In the surface of the stainless steel 304 are the most significant peaks of $\mathrm{O}, \mathrm{Fe}, \mathrm{Cr}$ and $\mathrm{Ni}$, which are usual metals present in steel oxide layers. The peaks with the highest intensity in the Inconel 738 spectrum are $\mathrm{Cr}$, $\mathrm{Ti}$ and $\mathrm{O}$.

\section{CONCLUSION}

To suggest materials behaviour in $\mathrm{Ca}$ looping technologies, three stainless steels and three nickel alloys were exposed for 200 hours in $900^{\circ} \mathrm{C} \mathrm{CO}_{2}$. This environment is an approximate simulation of ideal calciner conditions. However, the higher content of other substances will be present in real environment, which is the topic of our next research. This experiment was performed as a first test in the device designed for the purpose of testing construction materials for $\mathrm{Ca}$ looping equipment.

High temperature oxidation was observed on all tested materials. Furthermore, on the stainless steels 304, 316L, 316 Ti and nickel alloy Incoloy $800 \mathrm{H}$ appeared different grades of exfoliation caused by excessive thick oxide layers [7]. The exfoliation can lead to equipment damage and regulation devices blocking. Only the samples of Inconel 738 and Inconel 713 had even, coherent layers made of fine-grained oxides with high content of $\mathrm{Cr}$. Therefore, they could be the most promising as the construction materials for the given purpose. However, it is necessary to carry out more tests in different conditions to determine the range of oxide exfoliation of the stainless steels 304, 316L, 316Ti and Incoloy $800 \mathrm{H}$. One of the next goals is to analyse also the carburization of materials tested in this work.

\section{Acknowledgement}

Supported by grant from Norway (project $n r$ : NF-CZ08-OV-1-005-2015 "Research of high temperature $\mathrm{CO}_{2}$ sorption from flue gas using carbonate loop”) and from specific university research (MSMT No 20-SVV/2017). The authors thank Ing. Jiři Kubásek (UCT Prague) for SEM-EDS analyses and technical discussions.

\section{REFERENCES}

1. Blamey J., Anthony E. J., Wang J., Fenell P. S.: The calcium looping cycle for large-scale $\mathrm{CO}_{2}$ capture. Progress in Energy and Combustion Science 2010, 36, 260-279.

2. Ciahotný K., Staf M., Hlinčík T., Vrbová V., Tekáč J., Jiříček I.: Vysokoteplotní karbonátová smyčka - moderní metoda odstraňování $\mathrm{CO}_{2}$ ze spalin. Http://hitecarlo.vscht. $c z$ (Accesed 9 May 2017).

3. Sim S., Cole I.S., Choi Y.-S., Birbilis N.: A review of the protection strategies against internal corrosion for the safe transport of supercritical $\mathrm{CO}_{2}$ via steel pipelines for CCS purposes. International Journal of Greenhouse Gas Control 2014, 29, 185-199.

4. Firouzdor V., Sridharan K., Cao G., Anderson M., Allen T.R.: Corrosion of a stainless steel and nickel-based alloys in high temperature supercritical carbon dioxide environment. Corros. Sci. 2013, 69, 281-291.

5. Cao G. et al.: Corrosion of austenitic alloys in high temperature supercritical carbon dioxide. Corros. Sci. 2012, 62, 246-255.

6. Berstad D., Anantharaman R., Jordal K.: Post-combustion $\mathrm{CO}_{2}$ capture from a natural gas combined cycle by $\mathrm{CaO} /$ $\mathrm{CaCO} 3$ looping. International Journal of Greenhouse Gas Control 2012, 11, 25-33.

7. Rouillard F., Furukawa T.: Corrosion of 9-12Cr ferriticmartensitic steels in high-temperature $\mathrm{CO}_{2}$. Corros. Sci. 2016, 105, 120-132.

8. Gheno T., Monceau D., Zhang J.Q., Young D. J.: Carburisation of ferritic $\mathrm{Fe}$-Cralloys by low carbon activity gases. Corros. Sci. 2011, 53, 2767-2777.

9. Young D., Huczkowski P., Olszewski T., Huttel T., Singheiser L., Quadakkers W.J.: Non-steady state carburisation of martensitic $9-12 \% \mathrm{Cr}$ steels in $\mathrm{CO}_{2}$ rich gases at $550{ }^{\circ} \mathrm{C}$. Corros. Sci. 2014, 88, 161-169.

10. Převodní tabulka norem nerezových materiálů. http://www. inoxspol.cz/prevodni-tabulka-norem-nerezovych-materialu-rubrika.html, (Accesed 29 Feb 2017).

11. Vnouček, M.: Nikl a jeho slitiny, Titan a jeho slitiny. https:// www.opi.zcu.cz/download/nikl-titan-09_10.pdf (Accessed 12 Apr 2017).

12. Parks C. J.: Corrosion of Candidate High Temperature Alloys in Supercritical Carbon Dioxide. Master Thesis, Carleton University, 2013.

13. Xu N., Monceau D., Young D., Furtado J.: High temperature corrosion of cast heat resisting steels in $\mathrm{CO}+\mathrm{CO}_{2}$ gas mixtures. Corros. Sci. 2008, 50, 2398-2406.

14. Naing Aung N., Liu X.: Effect of $\mathrm{SO}_{2}$ in flue gas on coal ash hot corrosion of Inconel 740 alloy - A high temperature electrochemical sensor study. Corros. Sci. 2013, 76, 390-402.

15. Tan L., Anderson M., Taylor D., Allen T.R. Corrosion of austenitic and ferritic-martensitic steels exposed to supercritical carbon dioxide. Corros. Sci. 2011, 53, 3273-3280. 